\title{
Primipar Ve Multipar Gebelerde Doğum ve Doğum Sonu Döneme İlişkin Endişelerin Belirlenmesi
}

\author{
Determination of Anxieties Related to Delivery and Postpartum Period in Primiparous \\ and Multiparous Pregnant Women
}

\section{Zehra Demet ÜSTa ${ }^{a}$ Türkan PASINLİOĞLU ${ }^{b}$}

\begin{abstract}
ÖZET Amaç: Bu araştırma; primipar ve multipar gebelerde doğum ve doğum sonu döneme iliş̧kin endişelerin belirlenmesi amacıyla karşılaştırmalı tanımlayıcı olarak yapılmıştır. Materyal ve Metod: Araştırma Sağlık Bakanlığı Erzurum Nenehatun Kadın Doğum Hastanesi’ne doğum öncesi izlem için başvuran gönüllü 300 gebe üzerinde yapılmıştır. Veriler, 15 Mayıs-30 Aralık 2011 tarihleri arasında toplanmıştır. Verilerin toplanmasında Kişisel Bilgi Formu ve Doğum ve Doğum Sonrası Döneme İlişkin Endişeler Ölçeği kullanılmıştır. Verilerin değerlendirilmesinde; yüzdelik dağılımlar, ortalama, $t$ testi, tek yönlü varyans, Kruskall Wallis ve Mann-Whitney U testleri kullanılmıştır. Bulgular: Primipar gebelerin Doğum ve Doğum Sonrası Döneme İliş̧in Endişeler Ölçeği toplam puan ortalamasının $5.80 \pm 1.41$, multiparların $5.22 \pm 1.29$ olduğu ve aradaki farkın istatistiksel olarak anlamlı olduğu bulunmuştur $(\mathrm{p}<0.001)$. Primipar ve multipar gebelerin her ikisinde de ilgili ölçek alt boyutlarından alınan en yüksek puan ortalamasının Doğum Sırasında Sağlık Personelinin Davranışına Yönelik Endişeler alt boyutuna, en düşük puan ortalamasının ise Doğum Sonrası Eşinden Destek Alamama Endişesi alt boyutuna ait olduğu saptanmıştır. Sonuç: Gebelerin endişe düzeylerinin genel olarak orta derecede olduğu ve primipar gebelerde multiparlara göre daha yüksek olduğu saptanmıştır.
\end{abstract}

Anahtar Kelimeler: Gebelik, endişe, doğum, doğum sonu dönem.

\begin{abstract}
Aim:The purpose of this comparative descriptive study is to determine anxieties related to delivery and postpartum period in primiparous and multiparous pregnant women. Material and Method: The study was conducted on 300 voluntary pregnant women who applied for prenatal control to Erzurum Nenehatun Maternity Hospital of Ministry of Health. The data was collected between May 15, 2011 and December 30, 2011. Personal Information Form and Scale of Fears of Childbirth and Postpartum Period were used to collect data. Percentage distributions, mean, $t$ test, one-way variance analysis, Kruskall Wallis test and Mann-Whitney $\mathrm{U}$ test were used to evaluate data. Results: It was determined that total mean score of Scale of Fears of Childbirth and Postpartum Period of primiparous pregnant women was 5.80+1.41 and multiparous was 5.22 +1.29 and there was statistically significant difference $(\mathrm{p}<0.001)$. The highest mean score obtained by primiparous and multiparous pregnant women from sub-scales of the related scale was of the sub-scale anxieties towards behaviors of healthcare personnel during delivery; and the lowest mean score was of the sub-scale "anxiety of not receiving any support from her husband during postpartum period". Conclusion: It was determined that level of anxiety in pregnant women was generally medium; and higher in primiparous pregnant women in comparison to others.
\end{abstract}

Keywords: Pregnancy, anxiety, delivery, postpartum period.

Geliş Tarihi/Received:26.06.2015/Kabul Tarihi/Accepted:06.09.2015

a Yazışma Adresi/Crossepondence: Arş. Gör., Atatürk Üniversitesi Sağlık Bilimleri Fakültesi, Ebelik Bölümü, Kampüs/Erzurum, e-mail: zehra.ust@ hotmail.com, Tlf: 0(442)2311233/5791

b Prof.Dr., Atatürk Üniversitesi Sağllk Bilimleri Fakültesi, Hemşirelik Bölümü, Kampüs/Erzurum, e-mail: tpasin@atauni.edu.tr, Tlf: 0(442)2311233

*Çalışma Atatürk Üniversitesi Bilimsel Araştırma Projeleri birimi tarafindan desteklenmiş olup, 20-22 Haziran 2013 tarihleri arasında İzmir'de yapılan I. Ulusal Doğum Sonrası Bakım Kongresi'nde poster bildiri olarak sunulmuştur.

*Atatürk Üniversitesi Sağlık Bilimleri Enstitüsü Doğum, Kadın Sağlı̆̆ ve Hastalıkları Hemşireliği Anabilim Dalı, Yüksek Lisans Tezi-2012 


\section{Giriş}

Psikolojik, biyolojik ve duygusal değişimlerin yaşandığ 1 bir dönem olan gebelik, kadın hayatının en önemli olaylarından biridir. ${ }^{1} \mathrm{Bu}$ dönemde bazı kadınlarda çelişki, belirsizlik, içe dönüklük, pasif kişilik, bağımlılık, korku, kaygı gibi psikolojik değişikliklerle ortaya çıkan ruhsal sorunlar görülebilmektedir. Kayg1 özellikle doğum ve doğum sonrası dönemde kadınları olumsuz yönde etkilemektedir. ${ }^{2-4}$

$$
\text { Kayg1, yaşamın belirli }
$$

dönemlerinde zaman zaman yaşanan rahatsız edici endişe ve korku duygusudur. ${ }^{5}$ Kaygının yaşanması bir yere kadar sağlıklı iken, bir süre sonra kişinin yaşamını, olumsuz yönde etkilemektedir. Duygusal gerilimin, özellikle depresyon ve kaygının, gebelik ve doğum komplikasyonlarını artırdığı, yenidoğanın sağlığını olumsuz etkilediği, erken doğuma, düşük doğum ağırlığına ve rahim içi gelişim geriliğine neden olduğu bildirilmiştir. 6,7 Bundan dolayı gebelik dönemini sağlıklı ve rahat geçirmek kadın ve doğacak çocuk için çok önemlidir. ${ }^{8}$

Fizyolojik bir olay olarak değerlendirilen gebelik ve doğum kadın için büyük bir stres oluşturur. Özellikle ilk gebeliğinde kadın, tanımlayamadığı birçok yeni duyguyu bir arada yaşamakta, doğum anında karşılaşabileceği olayları tahmin edememektedir. ${ }^{9}$ Anne aday 1 bir taraftan kendisi için bilinmeyen doğum olayının meydana geleceği anı korku ve heyecanla beklerken, diğer taraftan bir canlı dünyaya getirmenin gururunu yaşar. ${ }^{9}$

Gebelik döneminde bazı kadınlar doğum eylemine yönelik farklı nedenlerden kaynaklanan korku duygusunu da yaşarlar. ${ }^{10}$ Yapılan çalışmalara göre doğumda bebeğin ölmesi ya da zarar görmesi, bebeğin malformasyonlu olmasi, ağr1 yaşama, sezaryen doğumun gerekli olması, doğum personeline güvenmeme, doğumda panik yaşama, kontrolsüz çığlık atma, kontrol kaybı yaşama, doğum eylemi boyunca yalnız olma, doğumun nasıl olacağını bilmeme ve ölüm gibi birçok düşünce korkuların nedenini oluşturmaktadır. ${ }^{11-14}$ Eylemin sona ermesi ve laktasyonun başlaması ile başlayan doğum sonu dönemde, önemli anatomik, fizyolojik ve psikolojik değişimler yaşanmaktadır. $\mathrm{Bu}$ dönemde annenin değişikliklere uyum sağlayıp, kendisi ve bebeğine bakabilmesi beklenmektedir. Doğum sonu ilk birkaç gün anne pasif ve bağımlı olup, daha çok alıcı konumundadır. Anne doğum sonu sürece uyum sağladıkça ilgisi bebeğe yönelir ve sütünün yetmeyeceği, ona bakamayacağı gibi endişelerle karşı karşıya kalır. ${ }^{15,16}$

Gebelik, doğum ve doğum sonu dönem ile ilgili fizyolojik değişiklikler, fiziksel komplikasyonlar, yorgunluk, yetersizlik, izolasyon, bebeğin gereksinimleri, rol çatışması, hem bebek hem de ailedeki diğer kişilerin sorumluluğunun devamı gibi nedenler annenin bu dönemdeki adaptasyonu zorlaştırmaktadır. Dinamik değişikliklerin olduğu bu dönemde bilgi verme, danışmanlık yapma ve ebeveynlerin endişelerini giderme gibi yaklaşımlar verilen hizmetin verimliliğini artırarak bu sürecin daha sağlıklı bir şekilde geçirilmesine katsı sağlayacaktır.

$\mathrm{Bu}$ araştırma, primipar ve multipar gebelerin doğum ve postpartum döneme ilişkin yaşadıkları endişeleri belirlemek amacıyla yapılmıştır.

\section{Gerec ve Yöntemler}

Tanımlayıcı ve gruplar arası karşılaştırmalı olan bu araştırma, Erzurum'da Sağlık Bakanlığı'na ait bir doğum hastanesinde 15 Mayıs 2011 -30 Aralık 2011 tarihleri arasında yapılmıştır. Araştırmanın evrenini, yukarıda belirtilen tarihler arasında hastanenin polikliniklerine başvuran ve araştırmaya katılabilme kriterlerini taşıyan (en az ilkokul mezunu olan, gebelikte riskli bir durumu bulunmayan ve doğal yolla gebe kalmış olan) gebeler oluşturmaktadır.

Çalışmaya alınması gereken minimum örneklem büyüklüğünü hesaplamak için evrendeki eleman sayısının bilinmediği 
durumlardaki örneklem seçme formülü kullanılmış ve 233 kişi olarak hesaplanmıştır. Örneklemin evreni temsil etme gücü düşünülerek çalışmaya 300 gebe (150 primipar, 150 multipar) dahil edilmiştir. ${ }^{17}$

Veriler araştırmacı tarafindan geliştirilen "Kişisel Bilgi Formu" ve Kitapçığlu ve ark. tarafindan 2007 yılında geliştirilen " Doğum ve Doğum Sonrası Döneme İlişkin Endişeler Ölçeği" kullanılarak toplanmıştır.

Kişisel Bilgi Formu; bu form, literatür bilgileri doğrultusunda araştırmacı tarafından geliştirilmiştir. Gebelerin sosyodemografik ve obstetrik özelliklerini belirleyebilecek türde toplam 16 soru içermektedir.

\section{Doğum ve Doğum Sonrası Döneme İlişkin Endişeler Ölçeği (DDSEÖ);} Kitapçıoğlu ve ark. tarafından 2007 yılında geliştirilmiştir. Ölçek, doğum ve doğum sonrası dönemde kadınların yaşadıkları endişeleri belirleyebilecek türde 10 alt boyuttan (61 ifadeden) oluşup, 5'li likert tiptedir. Her bir ifade için en düşük 1, en yüksek 5 puan verilmiştir. Ölçekte ters puanlanan ifadeler bulunmamaktadır. Ölçekte standartlaştırma sonrası elde edilen puanlar 1-10 arasında değişmektedir ve sandardizasyon sonras1 puanlar; 0.00-2.00: Çok düşük, 2.01-4.00: Düşük, 4.01-6.00: Orta, 6.01-8.00: Yüksek, 8.01-10.00: Çok yüksek olarak değerlendirilmektedir. ${ }^{10}$

Araştırmadan elde edilen veriler SPSS (Statistical Package for the Social Sciences) 13.0 paket programında değerlendirilmiştir. Verilerin değerlendirilmesinde; yüzdelik dağılımlar, ortalama, $\mathrm{t}$ testi, tek yönlü varyans, Kruskall Wallis ve Mann-Whitney U testleri kullanılmıştır.

Araştırmaya başlanmadan önce Kitapçıŏlu ve ark. geliştirmiş olduğu "Doğum ve Doğum Sonrası Döneme İlişkin Endişeler Ölçeği" için kullanma izni, Atatürk Üniversitesi Sağllk Bilimleri Enstitüsü Etik Kurulu'ndan onay ve Kadın
Doğum Hastanesi'nden uygulama izni alınmıştır.

Araştırma verilerinin toplanması esnasında gebelere araştırma hakkında bilgi verilerek "Aydınlatılmış Onam" ilkesi, araştırmaya katılıp katılmama konusunda özgür oldukları belirtilerek "Özerkliğe Saygı" ilkesi, araştırmaya katılan gebelerin bilgilerinin gizli tutulacağı belirtilerek "Gizlilik ve Gizliliğin Korunması" ilkesi yerine getirilmiştir. Anket ve ölçek uygulaması tamamlandiktan sonra gebelerin soruları yanıtlanmış, bilgi almak isteyen gebeler bilgilendirilmiştir.

\section{Bulgular}

Primipar gebelerin sosyo-demografik ve obstetrik özelliklerinin DDSEÖ puan ortalamaları ile karşılaştırılması Tablo 1'de verilmiştir. Buna göre; primipar gebelerin \%44.7'sinin 20-24 yaş aralığında, \%37.3'ünün eğitim durumunun ilköğretim düzeyinde, \%77.3'ünün çalışmadığ1 ve \%77.3'ünün ev hanımı olduğu saptanmıştır. Primipar gebelerin eşlerinin \%41.3'ünün eğitim durumunun yükseköğretim düzeyinde olduğu, \%46.7'sinin kamuda çalıştığ $1, \% 62.0$ 'ının ekonomik durumunun orta düzeyde olduğu, \% 72.7'sinin il merkezinde yaşadığı ve \% 67.3'ünün çekirdek aile yapısında olduğu saptanmıştır. Primipar gebelerin \%84.7'sinin 3 . trimesterde olduğu, \%80.0'ının normal doğum yapmayı planladıkları, \%85.3'ünün gebeliğini planladığ $1, \% 90.7$ 'sinin sosyal desteğinin olduğu ve \%82.7'sinin daha öncesinde herhangi bir eğitim/danışmanlık hizmeti almadığı saptanmıştır. Primipar gebelerin sosyo-demografik ve obstetrik özellikleri ile DDSEÖ puan ortalamaları ile karşılaştırıldığında eğitim durumu, eşin eğitim durumu, eşin mesleği ve planlanan doğum şekli ile DDSEÖ puan ortalamaları arasında anlamlı bir ilişki bulunmuştur $(\mathrm{p}<0.05)$. 
Tablo.1. Primipar Gebelerin Sosyo-Demografik ve Obstetrik Özelliklerinin DDSEÖ Puan Ortalamaları ile Karşılaştırılması

\begin{tabular}{|c|c|c|c|c|c|}
\hline & $\begin{array}{l}\text { Sosyo- } \\
\text { Demografik ve } \\
\text { Obstetrik } \\
\text { Özellikler }\end{array}$ & $\begin{array}{l}\text { Primipar } \\
\text { Gebeler } \\
(\mathrm{n}=150)\end{array}$ & $\begin{array}{c}\text { DDSEÖ } \\
\text { Puan } \\
\text { ortalaması }\end{array}$ & SS & $\begin{array}{l}\text { Test ve } \\
\text { p Değeri }\end{array}$ \\
\hline \multirow[t]{4}{*}{ Yaş } & $15-19$ & $13-8.7$ & 5.72 & 1.75 & \\
\hline & $20-24$ & $67-44.7$ & 6.01 & 1.36 & $\mathrm{KW}=3.854$ \\
\hline & $25-29$ & $53-35.3$ & 5.59 & 1.48 & $p>0.05$ \\
\hline & 30 ve üstü & $17-11.3$ & 5.64 & 1.06 & \\
\hline \multirow[t]{3}{*}{ Eğitim Durumu } & İlköğretim & $56-37.3$ & 6.16 & 1.40 & $\mathrm{~F}=4.427$ \\
\hline & Ortaöğretim & $54-36.0$ & 5.78 & 1.44 & $p<0.05$ \\
\hline & Yükseköğretim & $40-26.7$ & 5.31 & 1.26 & \\
\hline \multirow{2}{*}{ Çalışma Durumu } & Çalışıyor & $34-2.7$ & 5.92 & 1.22 & $t=0.60$ \\
\hline & Çalışmıyor & $116-77.3$ & 5.76 & 1.47 & $\mathrm{p}>0.05$ \\
\hline \multirow[t]{2}{*}{ Mesleği } & Kamu & $34-22.7$ & 6.01 & 1.18 & $\mathrm{t}=1.004$ \\
\hline & Ev hanımı & $116-77.3$ & 5.73 & 1.47 & $\mathrm{p}>0.05$ \\
\hline \multirow[t]{3}{*}{ Eşinin Eğitim Durumu } & İlköğretim & $34-22.7$ & 6.22 & 1.43 & $\mathrm{~F}=4.898$ \\
\hline & Ortaöğretim & $54-36.0$ & 6.00 & 1.39 & $p<0.05$ \\
\hline & Yükseköğretim & $62-41.3$ & 5.39 & 1.33 & \\
\hline \multirow[t]{3}{*}{ Eşinin Mesleği } & Kamu & $70-46.7$ & 5.51 & 1.32 & $\mathrm{~F}=3.843$ \\
\hline & Özel sektör & $45-30.0$ & 5.83 & 1.57 & $p<0.05$ \\
\hline & Serbest meslek & $35-23.3$ & 6.31 & 1.25 & \\
\hline \multirow{3}{*}{ Ekonomik Durum } & Kötü & $24-16.0$ & 6.25 & 1.40 & $\mathrm{KW}=4.215$ \\
\hline & Orta & $93-62.0$ & 5.63 & 1.43 & $p>0.05$ \\
\hline & İyi & $33-2.0$ & 5.94 & 1.31 & \\
\hline \multirow[t]{3}{*}{ Yaşadığı Yer } & İl & $109-72.7$ & 6.35 & 1.18 & $\mathrm{KW}=3.619$ \\
\hline & İlçe & $22-14.7$ & 5.51 & 1.57 & $\mathrm{p}>0.05$ \\
\hline & Köy & $19-12.6$ & 5.76 & 1.40 & \\
\hline \multirow{2}{*}{ Aile Tipi } & Çekirdek aile & $101-67.3$ & 5.98 & 1.32 & $\mathrm{t}=1.101$ \\
\hline & Geniş aile & $49-32.7$ & 5.71 & 1.45 & $\mathrm{p}>0.05$ \\
\hline \multirow{2}{*}{$\begin{array}{l}\text { Gebeliği Planlama } \\
\text { Durumu }\end{array}$} & Evet & $128-85.3$ & 5.77 & 1.47 & MWU $=1342.00$ \\
\hline & Hayır & $22-14.7$ & 5.92 & 1.06 & $\mathrm{p}>0.05$ \\
\hline \multirow{2}{*}{$\begin{array}{l}\text { Planlanan Doğum } \\
\text { Şekli }\end{array}$} & Normal Doğum & 13892.0 & 5.87 & 1.40 & MWU $=510$ \\
\hline & Sezaryen Doğum & $12-8.0$ & 4.93 & 1.36 & $\mathrm{p}<0.05$ \\
\hline \multirow[t]{3}{*}{ Trimester } & 1. Trimester & $6-4.0$ & 5.80 & 1.83 & $\mathrm{KW}=0.42$ \\
\hline & 2. Trimester & $17-11.3$ & 5.67 & 1.48 & $p>0.05$ \\
\hline & 3. Trimester & $127-84.7$ & 5.81 & 1.39 & \\
\hline \multirow[t]{2}{*}{ Sosyal Destek Varlığı } & Evet & $136-90.7$ & 5.80 & 1.42 & WU $=941.000$ \\
\hline & Hayır & $14-9.3$ & 5.77 & 1.37 & $\mathrm{p}>0.05$ \\
\hline Daha Önce & Almış & $26-17.3$ & 6.04 & 1.35 & MWU $=1403.00$ \\
\hline $\begin{array}{l}\text { Danışmanlık/Eğitim } \\
\text { Alma Durumu }\end{array}$ & Almamış & $124-82.7$ & 5.74 & 1.42 & $\mathrm{p}>0.05$ \\
\hline
\end{tabular}


Tablo.2. Multipar Gebelerin Sosyo-Demografik ve Obstetrik Özelliklerinin DDSEÖ Puan Ortalamaları ile Karşılaştırılması

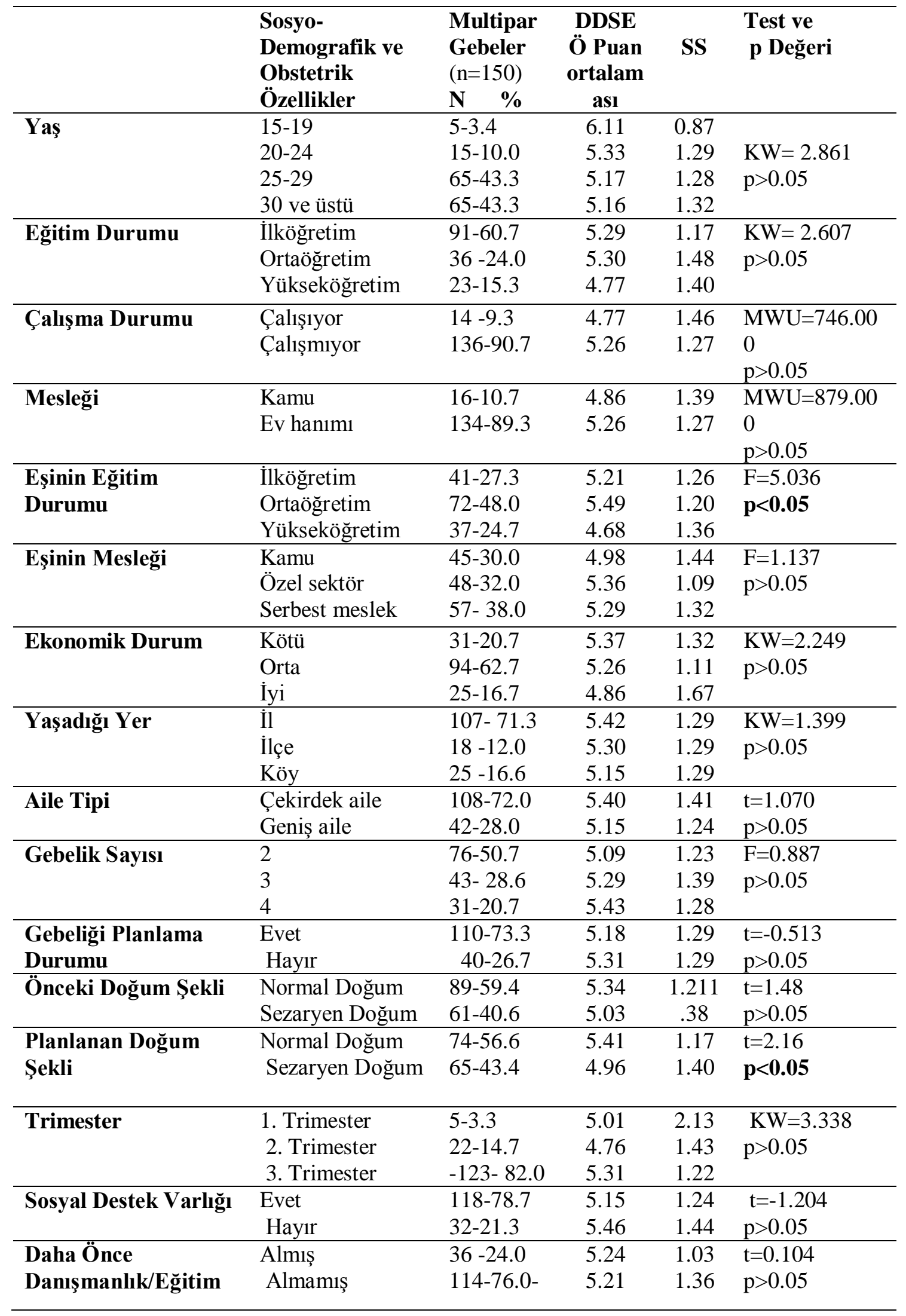


Tablo.3. Primipar ve Multipar Gebelerin DDSEÖ Puan Ortalamalarının Karşılaştırılması

\begin{tabular}{|c|c|c|c|}
\hline Gebelik Durumu & $\begin{array}{l}\text { DDSEÖ Puan } \\
\text { Ortalamaları }\end{array}$ & SS & $\begin{array}{l}\text { Test ve } \\
\text { p Değeri }\end{array}$ \\
\hline Primipar & 5.80 & 1.41 & $\begin{array}{l}\mathrm{t}=3,704 \\
\mathbf{p}<\mathbf{0 . 0 0 1}\end{array}$ \\
\hline Multipar & 5.22 & 1.29 & \\
\hline
\end{tabular}

Tablo.4. Primipar ve Multipar Gebelerin DDSEÖ Alt Boyut Puan Ortalamalarının Karşılaştırılması

\begin{tabular}{|c|c|c|c|}
\hline DDSEÖ Alt Boyutları & $\begin{array}{l}\text { Primipar } \\
\text { Gebeler } \\
\text { Ortalama } \pm \text { SS }\end{array}$ & $\begin{array}{c}\text { Multipar } \\
\text { Gebeler } \\
\text { Ortalama } \pm \text { SS }\end{array}$ & $\begin{array}{c}\text { Test ve } \\
\text { p Değeri }\end{array}$ \\
\hline 1. Bebeğe İlişkin Endişeler & $5.42 \pm 1.75$ & $5.37 \pm 1.98$ & $\begin{array}{l}t=0.234 \\
p>0.05\end{array}$ \\
\hline $\begin{array}{l}\text { 2. Doğum Eylemine İlişkin } \\
\text { Endişeler }\end{array}$ & $6.81 \pm 1.85$ & $5.86 \pm 1.97$ & $\begin{array}{l}t=4.257 \\
\mathbf{p}<\mathbf{0 . 0 0 1}\end{array}$ \\
\hline $\begin{array}{l}\text { 3. Doğum Sonrası Emzirmeye } \\
\text { İlişkin Endişeler }\end{array}$ & $6.54 \pm 2.45$ & $5.70 \pm 2.28$ & $\begin{array}{c}t=3.080 \\
\mathbf{p}<\mathbf{0 . 0 5}\end{array}$ \\
\hline $\begin{array}{l}\text { 4. Doğum Sonrasında Bebek } \\
\text { Bakımında Yetersiz Kalma } \\
\text { Endişesi }\end{array}$ & $5.46 \pm 1.97$ & $4.14 \pm 1.77$ & $\begin{array}{l}t=6.097 \\
\mathbf{p}<\mathbf{0 . 0 0 1}\end{array}$ \\
\hline $\begin{array}{l}\text { 5. Doğum Sonrası Sosyal } \\
\text { Yaşama İlişkin Endişeler }\end{array}$ & $4.69 \pm 2.17$ & $4.63 \pm 2.14$ & $\begin{array}{l}t=0.214 \\
p>0.05\end{array}$ \\
\hline $\begin{array}{l}\text { 6. Doğum Sonu Bebek ve } \\
\text { Loğusa Sağlığına İlişkin } \\
\text { Endişeler }\end{array}$ & $5.47 \pm 1.68$ & $5.19 \pm 1.70$ & $\begin{array}{l}t=1.390 \\
p>0.05\end{array}$ \\
\hline $\begin{array}{l}\text { 7. Doğum Sonrası Eşinden } \\
\text { Destek Alamama Endişesi }\end{array}$ & $4.10 \pm 1.86$ & $3.97 \pm 1.65$ & $\begin{array}{l}t=0.603 \\
p>0.05\end{array}$ \\
\hline 8. Travay Öncesi Endişeler & $6.01 \pm 2.52$ & $5.33 \pm 2.32$ & $\begin{array}{l}\mathrm{t}=2.428 \\
\mathbf{p}<\mathbf{0 . 0 5}\end{array}$ \\
\hline $\begin{array}{l}\text { 9. Doğum Sırasında Sağlık } \\
\text { Personelinin Davranışına } \\
\text { Yönelik Endişeler }\end{array}$ & $6.98 \pm 2.34$ & $6.22 \pm 2.40$ & $\begin{array}{l}t=2.772 \\
\mathbf{p}<\mathbf{0 . 0 5}\end{array}$ \\
\hline 10. Sezaryen Olma Endişesi & $6.50 \pm 2.68$ & $5.74 \pm 2.61$ & $\begin{array}{c}\mathrm{t}=2,462 \\
\mathbf{p}<\mathbf{0 . 0 5}\end{array}$ \\
\hline
\end{tabular}

Tablo 2'de multipar gebelerin sosyodemografik ve obstetrik özelliklerinin DDSEÖ puan ortalamaları ile karşılaştırılması verilmiştir. Buna göre; multipar gebelerin \%43.3'ünün 30 ve üstü yaş aralığında olduğu, \%60.7'sinin eğitim 
durumunun ilköğretim düzeyinde olduğu, \%90.7'sinin çalışmadığı, \%89.3'ünün ev hanımı olduğu saptanmıştır. Multipar gebelerin eşlerinin \%48.0'ının eğitim durumunun ortaöğretim düzeyinde olduğu ve \%38.0'ının serbest meslekte çalıştığ bulunmuştur. Multipar gebelerin $\% 62.7$ 'sinin ekonomik durumunun orta düzeyde olduğu, \%71.3'ünün il merkezinde yaşadığ 1 ve \%72.0'ının çekirdek aile yapısında olduğu saptanmıştır. Multipar gebelerin \%50.7'sinin 2. gebeliği olduğu, $\% 82.0$ 'ının 3. trimesterde olduğu, \%54.7'sinin önceki doğum şeklinin normal doğum olduğu, \%49.3'ünün ise şimdiki gebeliği için normal doğum planladıkları bulunmuştur. Multipar gebelerin \%73.3'ünün şimdiki gebeliğini planladığı, $\% 78.7$ 'sinin sosyal desteğinin olduğu ve \%76.0'ının daha öncesinde herhangi bir eğitim/danışmanlık hizmeti almadığ belirlenmiştir. Multipar gebelerin sosyodemografik ve obstetrik özellikleri ile DDSEÖ puan ortalamaları ile karşılaştırıldığında eşin eğitim durumu ve planlanan doğum şekli ile DDSEÖ puan ortalamaları arasında anlamlı bir ilişki bulunmuştur $(\mathbf{p}<\mathbf{0 . 0 5})$.

Tablo 3'te primipar ve multipar gebelerin DDSEÖ puan ortalamalarının karşılaştırılması incelenmiş, primipar gebelerin DDSEÖ puan ortalamalarının $5.80 \pm 1.41$, multipar gebelerin DDSEÖ puan ortalamalarının $5.22 \pm 1.29$ olduğu ve aradaki farkın istatistiksel olarak anlamlı olduğu bulunmuştur $(\mathbf{p}<\mathbf{0 . 0 0 1})$.

Tablo 4'te primipar ve multipar gebelerin DDSEÖ alt boyut puan ortalamalarının karşılaştırılması incelenmiştir. Buna göre; primipar ve multipar gebelerde 2., 3., 4., 8., 9., ve 10. alt boyut puan ortalamalar1 arasındaki farkın istatistiksel olarak anlamlı olduğu $(\mathbf{p}<\mathbf{0 . 0 0 1}, \mathbf{p}<\mathbf{0 . 0 5}), 1 ., 5 ., 6$. ve 7 . alt boyut puan ortalamaları arasındaki farkın istatistiksel olarak anlamlı olmadığı bulunmuştur.

\section{Tartışma}

Primipar gebelerin sosyo-demografik ve obstetrik özellikleri ile DDSEÖ puan ortalamaları ile karşılaştırıldığında eğitim durumu, eşin eğitim durumu, eşin mesleği ve planlanan doğum şekli ile DDSEÖ puan ortalamaları arasında anlamlı bir ilişki bulunmuştur $(\mathbf{p}<\mathbf{0 . 0 5})$. Gözüyeşil ve ark. ${ }^{78}$ çalışmasında da gebelerin depresyon puan ortalamaları ile eğitim durumları karşılaştırılmış, ilkokul mezunu olan gebelerin depresyon puan ortalamalarının daha yüksek olduğu belirtilmiştir. Gözüyeşil ve ark. ${ }^{17}$ ile Kılıçarslan' ${ }^{18}{ }^{18}$ çalışmalarında gebenin eşinin eğitim düzeyinin artmasının, gebede depresyon durumunu azalttığı bulunmuştur. Buna karşın Akbaş ve ark. ${ }^{19}$ yaptı̆̆ 1 araştırmada eş eğitim durumu ile anksiyete ve depresyon arasında ilişki bulunamamıştır.Arslan' 'n ${ }^{20}$ araştırmasında araştırmaya katılan gebelerin eşlerinin meslekleri ile anksiyete puanı arasında anlamlı farklılık gözlenmediği fakat eşlerinin meslekleri ile depresyon puanları arasında anlamlı farklılık gözlendiği bulunmuştur.

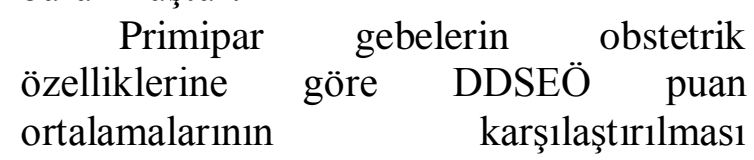
incelendiğinde; primipar gebelerin obstetrik özelliklerinin hiçbirinde ilgili ölçek puan ortalamaları arasındaki farkın istatistiksel olarak anlamlı olmadığı bulunmuştur ( $>>0.05$ ).

Multipar gebelerin sosyodemografik ve obstetrik özellikleri ile DDSEÖ puan ortalamaları ile karşılaştırıldığında eşin eğitim durumu ve planlanan doğum şekli ile DDSEÖ puan ortalamaları arasında anlamlı bir ilişki bulunmuştur $\quad(\mathbf{p}<\mathbf{0 . 0 5}) . \quad$ Araştırmayı destekler nitelikte Gözüyeşil ve ark. ${ }^{17}$ ile Kılıçarslan' ${ }^{18}{ }^{18}$ çalışmalarında da gebenin eşinin eğitim düzeyinin artmasının, gebede depresyon durumunu azalttığı belirtilmiştir. Buna karşın Akbaş ve ark. ${ }^{19}$ yaptığ 1 çalışmada eş eğitim durumu ile anksiyete ve depresyon arasında anlamlı bir ilişki bulunamamıştır. 
Hem primipar hem de multipar gebelerde DDSEÖ puan ortalamasının normal doğum planlayan gebelerde yüksek olduğu saptanmıştır. Bunun, yaşanan deneyimlerin kadınlar arasında paylaşılması ve normal doğumun ağrılı ve kanlı bir eylem olarak bilinmesinden kaynaklandığı düşünülmektedir. Yapılan araştırmalarda da gebelerin en fazla doğum ağrısı olmak üzere; doğumda panik yaşama, kendisinin doğum yapabilecek yetenekte olmadığını düşünme, başaramamaktan korkma, doğumda yanlış bir davranışta bulunarak kendisine ve bebeğine zarar vermekten korkma gibi nedenlerle normal doğum eyleminden korktuğu belirtilmiştir. ${ }^{9,12,21-24}$

DDSEÖ puan ortalamalarına bakıldığında; primipar gebelerde 5.80 +1.41 , multipar gebelerde 5.22+1.29 olduğu ve puan ortalamaları arasındaki farkın istatistiksel olarak anlamlı olduğu bulunmuştur $(p<0.001)$. Buna göre gebelerin endişe düzeyi orta derecede olup, primipar gebelerde daha yüksektir. Araştırma bulgusunu destekleyecek şekilde, Akbaş ve ark. ${ }^{19}$ ile Kaplan ve ark.'nın ${ }^{25}$ yaptıkları çalışmalarda; ilk gebeliği olanlarda daha fazla durumsal kayg1 saptanmıştır. Buna karşılık Arslan'nın ${ }^{20}$ yaptığı çalışmada; gebelik sayısı arttıkça depresyon ve anksiyete puanlarının yükseldiği belirlenmiştir.

$\mathrm{Bu}$ araştırmada primipar gebelerde endişe düzeyinin daha yüksek olmasının nedeninin doğum ve doğum sonu dönem ile ilgili bilgi eksikliğinden kaynaklandığı düşünülmektedir. Primipar gebeler deneyimsiz oldukları için doğum anında ve doğumdan sonra karşılaşabilecekleri olaylar1 tahmin edememekte, bu da gebelerin endişesinin artmasına neden olabilmektedir. Araştırma bulgularına göre multipar gebelerde de endişe düzeyi orta derecedir. Doğum ve doğum sonu dönem ile ilgili bilgi sahibi olmanın endişe düzeyini azalttığı fakat endişeyi ortadan kaldırmadığı söylenebilir. Doğumun ağrılı ve kanlı bir eylem olması ve kadının mahremiyetini tehdit etmesi nedeniyle tüm gebelerde bir miktar endişenin her zaman var olacağ1 düşünülmektedir.

Primipar ve multipar gebelerin DDSEÖ'nin alt boyutlarına göre puan ortalamalarının karşılaştırılması incelendiğinde; araştırmada en yüksek endişe düzeyi Doğum Sirasında Sağlık Personelinin Davranışına Yönelik Endişeler alt boyutuna ait olduğu görülmektedir $(\mathbf{p}<\mathbf{0 . 0 5})$. Sjögren'in ${ }^{26}$ yaptığı çalışmada gebelik döneminde saptanan en önemli korku nedeninin doğumda görev alan sağlik personeline güven eksikliği olarak belirtilmiştir.İkinci surada Doğum Eylemine İlişkin Endişeler alt boyutu gelmektedir $(p<0.001)$. Yaşanan olumsuz deneyimlerin kadınlar arasında paylaşılarak yayılmasının ve görsel medyada gösterilen ağrılı doğum sahnelerinin özellikle primipar gebelerde endişenin artmasına neden olduğu düşünülmektedir. Benzer araştırmalarda gebelerde en fazla doğum ağrısı olmak üzere; doğumda panik yaşama, kendisinin doğum yapabilecek yetenekte olmadığını düşünme, başaramamaktan korkma, doğumda yanlış bir davranışta bulunarak kendisine ve bebeğine zarar vermekten korkma gibi nedenlerle normal doğum eyleminden de korktuğu ve bunun da isteğe bağlı sezaryen oranını artırdığ1 belirtilmiștir. ${ }^{9,12,21-24}$

Üçüncü sırada Doğum Sonrası Emzirmeye İlişkin Endişeler alt boyutu gelmektedir $\quad(\mathbf{p}<\mathbf{0 . 0 5}) . \quad$ Arslan' $^{20}$ çalışmasında da primipar annelerin danışmanlık sürecinde danıştıkları konuların başında bebek beslenmesi ile ilgili konuların geldiği belirtilmiştir. Doğaner' in ${ }^{27}$ çalışmasında da doğum sonu hastaneden taburcu olurken bilgi alan annelerin \%31.9'unun emzirme ve meme bakımı konusunda bilgi aldıkları saptanmıştır. Yapılan çalışmalar annelerin daha çok bebek beslenmesine yönelik endişe yaşadığını göstermektedir.

Dördüncü sirada Sezaryen Olma Endişesi alt boyutu gelmektedir $(\mathbf{p}<\mathbf{0 . 0 5})$. Bununla ilgili yapılmış bir araştırmaya rastlanılmamıştır. Araştırmada multipar gebelerin \%32.0'ının daha önceden 
sezaryen doğum, \%8.7'sinin de hem normal hem de sezaryen doğum yaptıkları bulunmuştur. Yani multipar gebelerin yaklaşık yarısının sezaryen ile doğum deneyimleri mevcuttur. Buna rağmen onlarda da bu konu ile ilgili endişe düzeyi yüksektir. Sezaryen sonrası rahatsızlıkların normal doğuma göre daha fazla yaşanmasının bunu deneyimlemiş olan gebelerde endişeye neden olduğu düşünülmektedir. Diğer taraftan, primipar gebelerin endişe düzeyinin multiparlara göre daha yüksek olmasının nedeni, sezaryenin bir ameliyat olması ve daha önce yaşanmamış olmasından kaynaklanabilir.

Beşinci sırada Travay Öncesi Endişeler alt boyutu gelmektedir $(\mathbf{p}<\mathbf{0 . 0 5})$. Bununla ilgili yapılmış bir araştırmaya rastlanılmamıştır. Gebelerin travay öncesi endişelerinin bu süreçte gerçekleşecek olaylar1 tahmin edememelerinden kaynaklandığı düşünülmektedir.

Altınc1 sirada Doğum Sonu Bebek ve Loğusa Sağlığına İlişkin Endişeler alt boyutu gelmektedir. Puan ortalamaları arasındaki farkın istatistiksel olarak anlamlı olmadığ $1 \quad$ saptanmıştır $\quad(\mathrm{p}>0.05) . \quad \mathrm{Bu}$ araştırmanın bulgularını destekleyecek şekilde Arslan'nın ${ }^{20}$ ve Doğaner'in ${ }^{27}$ yaptıkları çalışmalarda; annelerin en sık danışmanlık istedikleri konuların başında yukarıda da belirtildiği gibi bebek beslenmesinin geldiği, bunu sirasiyla bebeğin hastalığ bebek banyosu-vücut bakımı, göz ve göbek bakımının takip ettiği belirtilmektedir.

$$
\text { Yedinci sirada Doğum }
$$

Sonrasında Bebek Bakımında Yetersiz Kalma Endişesi alt boyutu gelmektedir (p<0.001). Başer ve ark. ${ }^{28}$ çalışmasında ilk gebeliği olan annelerin bebek bakımı konusunda daha fazla güçlük yaşadıkları belirtilmiştir. $\mathrm{Bu}$ sonuç araştırma bulgusuyla uyumludur. Bebek bakımı konusunda deneyimsiz olan primipar gebelerin bu konuda eğitim ve danışmanlığa daha fazla ihtiyaçları olduğu görülmektedir.

Sekizinci sırada Bebeğe İlişkin Endişeler alt boyutu gelmektedir ( $p>0.05)$.
Araştırma bulgusunu destekleyecek şekilde, Di Renzo ve ark. ${ }^{30} 810$ İtalyan gebe üzerinde yaptığı araştırmada; gebelerin $1 / 3$ 'ünden fazlasinın hasta veya özürlü bebek doğurma korkusunun olduğu belirtilmiştir. Hem primipar hem multipar gebelerin her ikisi de doğuracakları bebekle ilgili olarak belirli düzeyde endişe taşımaları, sonucun ne olacağı kesin olarak bilinmeyen bir süreç olan doğum eylemi ve neticeleri hakkında eğitim ve danışmanlığa ihtiyaç duyduklarını göstermektedir.

Dokuzuncu sirada Doğum Sonrası Sosyal Yaşama İlişskin Endişeler alt boyutu gelmektedir ( $p>0.05)$. Bu konuyla ilgili yapılmış bir çalışmaya rastlanılmamıştır. Toplumumuzda genellikle aile, akraba ve tanıdıklar arasında sürekli bir iletişim vardır. Doğum sonu dönemde bu iletişim loğusa ziyaretleri şeklinde kendini gösterir. Bu ziyaretlerin loğusalarda sosyal yaşama pozitif etkisinin olduğu düşünülmektedir.

Son olarak Doğum Sonrası Eşinden Destek Alamama Endişesi alt boyutu gelmektedir $(p>0.05)$. Bu konuyla ilgili yapılmış bir çalışmaya rastlanılmamıştır. Her iki gruptaki gebelerin de sosyal destek alma durumunun yüksek olması ve çiftlerin büyük çoğunluğunun bu gebeliği planlamış olması nedeniyle; gebelerde doğum sonras1 eşinden destek alamama endişesinin çok fazla olmadığı düşünülmektedir.

\section{Sonuç ve Öneriler}

Araştırma sonucunda; primipar ve multipar gebelerin endişe düzeyinin orta derecede olduğu ve hem primipar hem de multipar gebelerin ilgili ölçek alt boyutlarından alınan en yüksek puan ortalamasının "Doğum Sırasında Sağlik Personelinin Davranışına Yönelik Endişeler" alt boyutuna, en düşük puan ortalamasının ise "Doğum Sonrası Eşinden Destek Alamama Endişesi" alt boyutuna ait olduğu bulunmuştur. Bu sonuçlar doğrultusunda;

- Gebelerin gebelik ve doğum hakkında bilgilendirilmesi amacıyla gebe eğitim sınıfları oluşturulup, yaygınlaştırılması, 
- Birinci basamak sağlık kuruluşları ve hastanelere başvuran gebelerin endişelerinin belirlenip, gerekli eğitimlerin verilmesi,

- Sağlık personelinin gebelere destek vermesi konusunda bilinçlendirilmesi,

- Hastanelerin doğum kliniklerinde sosyal hizmet uzmanı ve psikolog bulundurulması önerilebilir.

\section{Kaynaklar}

1. Taşkın L. Gebeliğin Psikososyal ve Kültürel Boyutları. Doğum ve Kadın Sağlığı Hemşireliği [Birth and Women's Health Nursing]. 11. Bask1. Ankara. Sistem Ofset Matbaac1lik; 2012. p. 215-220.

2. Erdem Ö. Prepartum ve postpartum dönemde annelerin duygu durumlarinın incelenmesi [Investigation of moods of mothers during prepartum and postpartum period][Uzmanlık Tezi]. Dicle Üniversitesi Tıp Fakültesi Aile Hekimliği Anabilim Dalı [Department of Family Medicine, Dicle University Faculty of Medicine], Diyarbakır, Türkiye, 2009.

3. Kaplan S. Bahar A. Sertbaş G. Gebelerde doğum öncesi ve doğum sonras1 dönemlerde durumluksürekli kaygı düzeylerinin incelenmesi [Evaluation of the anxiety levels of

pregnant women at prenatal and postnatal period]. Atatürk Üniversitesi Hemşirelik Yüksekokulu Dergisi [Journal of Anatolia Nursing and Health Sciences] 2007; 10: 1.

4. Beck CT. Predictors of postpartum depresyon, an update. Nursing Research. 2001; 50(5): 275.

5. Sertbaş G. Bahar A. Anksiyete ve anksiyete ile baş etmede hemşirelik girişimleri [Nursing interventions for coping with anxiety and anxiety]. Hemşirelik Forumu
Dergisi [Journal of Nursing Forum]. 2004; 5: 39-44.

6. Berle J.I. Mykletun A. Daltveit AK. Rasmussen S. ve ark. Neonatal Outcomes In Offspring of Women with Anxiety and Depression During Pregnancy. A link age study from the nord-trondelaghealthstudy (hunt) andmedical birth registry of norway. ArchWomen Ment Health. 2005; 8: 181-89.

7. Mc Elderry D. Screening of adolescent females for depression before, during and after pregnancy. Opinions in Pediatric and Adolescent Gynecology 2001; 1(14): 131-33.

8. Şahin EM, Kılıçarslan S. Son trimester gebelerin depresyon ve kaygı düzeyleri ile bunları etkileyen etmenler [Depressive, anxiety levels and affecting factors of third trimester pregnant women]. Trakya Üniversitesi Tıp Fakültesi Dergisi [Medical Journal of Trakya University]. 2010; 27(1): 51-57.

9. Sayıner FD. Özerdoğan N. Doğal doğum[Natural birth]. Maltepe Üniversitesi Hemşirelik Bilim ve Sanat1 Dergisi [Journal of Nursing Science and Art, Maltepe University]. 2009; 2(3): 143-148.

10. Kitapçığ lu G. Yanıkkerem E. Sevil Ü. Yüksel D. Gebelerde doğum ve postpartum döneme ilişkin endişeler; bir ölçek geliştirme ve validasyon çalışması [Fear of Childbirth and The Postpartum Period: A Scale Development and Validation Study]. Adnan Menderes Üniversitesi Tıp Fakültesi Dergisi [Journal of Adnan Menderes University Medical Faculty]. 2008; 9(1): 47-54.

11. Serçekuş P. Nullipar kadınlarda normal spontan doğuma ilişkin korkular ve nedenlerinin incelenmesi [Investigation that fears associated with normal spontaneous delivery and their reasons][Yüksek 
Lisans Tezi]. Dokuz Eylül Üniversitesi Sağlık Bilimleri Enstitüsü Hemşirelik Anabilim Dalı [Institute of Health Sciences Nursing Department, Dokuz Eylül University], İzmir, Türkiye, 2005.

12. Ryding EL. Investigation of 33 women who demanded a ceserean section for personal reasons. Acta Obstetricia Et Gynecologicia Scandinavica. 1993; 72: 280-285.

13. Ryding EL. Wijma B. Wijma K. Rydhström H. Fear of childbirth during pregnancy may increase the risk of emergency ceserean section. Acta Obstetricia Et Gynecologicia Scandinavica. 1998; 77: 542-547.

14. Melender HL. Experiences of fears associated with pregnancy and childbirth. a study of 329 pregnant women. Birth. 2002; 29(2): 101109.

15. Beydağ KD. Doğum sonu dönemde anneliğe uyum ve hemşirenin rolü. TSK Koruyucu Hekimlik Bülteni.2007; 6:6.

16. Marakoğlu K, Özdemir S, Çivi S. Postpartum Depresyon. Türkiye Klinikleri Tıp Bilimleri Dergisi. 2009; 29(1):206-214.

17. Karataş N. [Araştırmada Örnekleme]. Erefe İ, editör. Hemşirelikte Araştırma İlke, Süreç ve Yöntemleri. İstanbul: Odak Ofset; 2004. p. 125-138.

18. Gözüyeşil YE, Şirin A, Çetinkaya Ş. Gebe kadinlarda depresyon durumu ve bunu etkileyen etmenlerin incelenmesi [Investigation of affecting factors and state of depression in pregnant women]. Frrat Sağlık Hizmetleri Dergisi[Furat University Journals of Health Sciences] 2008; 3(9): 39-66.

19. Kilıçarslan S. Edirne şehir merkezindeki son trimester gebelerin sosyodemografik özellikleri, yaşam kaliteleri, kayg1 düzeyleri[Sociodemographic characteristics, health qualities and anxiety levels of third trimester pregnant women living in Edirne][Uzmanlık Tezi]. Trakya Üniversitesi Tıp Fakültesi Aile Hekimliği Anabilim Dalı [Department of Family Medicine, Trakya University Faculty of Medicine], Edirne, Türkiye, 2008.

20. Akbaş E, Vırıt O, Kalenderoğlu A. ve ark. Gebelikte sosyodemografik değişkenlerin kaygı ve depresyon düzeyleriyle ilişkisi[Association Between Sociodemographic Variables with the Levels of Depression and Anxiety in Pregnancy]. Nöropsikiyatri Arşivi[Archives of Neuropsychiatry] 2008; 45: 85-91.

21. Arslan B. Gebelerde anksiyete ve depresyonla ilişkili sosyodemografik özellikler[Sociodemographic features associated with anxiety and depression in pregnant women][Uzmanlık Tezi],Süleyman Demirel Üniversitesi Tıp Fakültesi, Aile Hekimliği Anabilim Dalı [Department of Family Medicine, Süleyman Demirel University, Faculty of Medicine] Isparta, Türkiye, 2010.

22. Chong ESY, Mongelli M. Attitudes of Singapore women toward cesarean and vaginal deliveries. Journal of Gynecology and Obstetrics 2003; 80: 189-194.

23. Duman Z, Koken GN, Şahin FK, Coşar E, Arıöz DT, Aral D. Sağlik çalışanlarının normal doğum ve sezaryen ile ilgili düşünceleri[Normal and Cesarean Birth Related Thoughts of Health Workers]. Perinatoloji Dergisi[Journal of Perinatology] 2007; 15(1): 7-11.

24. Chigbu CO, Ezeome IV, Iloabachie GC. Cesarean section on request in a developing country. Journal of Gynecology and Obstetrics 2007; 96: 54-56. 
25. Sayın C, Berberoğlu U, Varol F. Sezaryenle doğum yapmış sağlık personelinde doğum sonrası memnuniyet ve takip edilen gebelikte doğum şekli tercihi[Cesarean birth in a health after birth followed by satisfaction and preferred mode of delivery in pregnancy staff]. $\mathrm{T}$ Klin Jinekol Obst. 2004; 18(2): 82-88.

26. Kaplan S, Bahar A, Sertbaş G. Gebelerde doğum öncesi ve doğum sonras1 dönemlerde durumluluk kayg1 düzeylerinin incelenmesi[Evaluation of the Anxiety Levels of Pregnant Women at Prenatal and Postnatal Period]. Atatürk Üniversitesi Hemşirelik Yüksekokulu Dergisi[Journal of Anatolia Nursing and Health Sciences] 2007; 10(1): 113-121.

27. Sjögren B. Reasons for anxiety about childbirth in 100 pregnant women. J Psychosom Obstet Gynaecol 1997 Dec; 18(4): 266272.

28. Doğaner G. Vajinal yolla doğum yapan kadınların erken postpartum dönemde kendisinin ve yenidoğanın bakımına yönelik yaşadıkları sorunlarin belirlenmesi[Determining the problems they have in caring for themselves and their baby in the early post-partum period in women who have done a vaginal birth][Yüksek Lisans Tezi] Cumhuriyet Üniversitesi Sağlık Bilimleri Fakültesi Hemşirelik Programi[Department of Nursing, Cumhuriyet University Faculty of Health Sciences] Sivas, Türkiye, 2005.

29. Başer M, Mucuk S, Korkmaz Z, Seviğ Ü. Postpartum dönemde anne ve babaların yenidoğan bakımına ilişkin gereksinimlerinin belirlenmesi[The Determination of Mother and Father Newborn Care Needs in Postpartum Period]. Sağlık
Bilimleri Dergisi[Journal of Health Sciences] 2005; 14 ( Ek Say1: Hemşirelik Özel Sayıs1): 54-58.

30. DiRenzo G, Polito P, Volpe A, Anceschi M, Guidetti R. A multicentric study on fear of childbirth in pregnant women at term. J Psychosom Obstet Gynecol 1984; 3: 155-163. 